河床波上の流れの構造と浮遊粒子の拡散過程について

Structure of Flow and Dispersion Process of Suspended Particle over Two-Dimensional Dunes

$\begin{array}{llllll}\text { 京都大学工学部 } & \text { 中 } 川 & \text { 博 } & \text { 次 Hiroji NAKAGAWA } \\ \text { 京都大学工学部 } & \text { 村 } & \text { 上 } & \text { 五 Shogo NURAKAMI } \\ \text { 京都大学大学院 } & \text { 後 } & \text { 藤 } & \text { 志 Hitoshi GOTOH }\end{array}$

The characteristics of turbulent flows over the two-dimensional dunes has been investigated in two methods, namely measurements with the aid of hot-film anemometer and numerical simulation by $k-\varepsilon$ turbulent model.

The computed resuls of $k-\varepsilon$ model agrees well with the measured data of mean velocity and turbulence intensities profiles.

Based on the calculated flow field, the motion of the suspended particle traced by MonteCarlo simulation, in which Markov process model is adopted.

Finally the non-equilibrium dispersion process of suspended particle over the dunes is predicted based on the proposed simulation model. The profiles of the suspended particle concentration over dunes agrees well with the results of experiment, which indicates the applicability of present simulation to the sediment transport in the flow over non-uniform boundaries.

Keywords: ounes, $b-\varepsilon$ nodel, Honte-Carlo sinulation, Harkov process, consentration

\title{
1.はしめに
}

河床波の発生・発達過程を墇流砂のみの非平衡性から論じる際には，底面せん断応力分布と河床形状の位 相差の果たす役割が重要であり，このため従来から河床波面上のせん断応力分布についての多くの研究が行 われ, 河床波上の非平衡掃流砂過程が鍽じられてきた. 掃流力が比較的小さい河床波の発生過程においては, 掃流砂のみを論じれば十分であるが，発達・変形遇程においては，浮遊砂の寄与分も無視できない，浮遊砂 は流れの全領域に分布することから，単に底面せん断応力分布に留まらず，河床波上流れの構造についての 知見が必要不可欠である. 更に, 発達・変形遗程において河床波は非対称性を增し, 流れは剥噰流となり, このような境界条件の複雑さ故, 従来の解析的方法は, 流速分布・乱れ强度分布についての定量的情報を得 る上で十分とは言えない。

本研究では, 河床波上流れの構造について, 熱膜流速計による計測とk- $\varepsilon$ 乱流モデルによる数值シミュレ ーションの両面から唡討し，それに基ついて模擬される流れ場における浮遊粒子の拡散遇程を運動方程式に 基づいて追跡し，河床波上流れ場における浮遊砂搌度分布の推定法を示すことを目的とする.

\section{2. 河床波上法九の計测}

実験に用いた水路は，全長 $12 \mathrm{~m}$,幅 $50 \mathrm{~cm}$, 深さ $20 \mathrm{~cm}$ のアクリル䡛 可変勾配水路であり, 上流端に設珇されたハニカム整流装置の 下流に粒径 $0.128 \mathrm{~cm}$ の球状粒子で粗度付けされた $1.8 \mathrm{~m}$ 平坦部を 設け, その下流に同様の粗度を有する波長 $40 \mathrm{~cm}$, 波高 $2 \mathrm{~cm}$ の 2 次 元 3 角形モデル河床波を10波設置した。計測は，上流から8波目

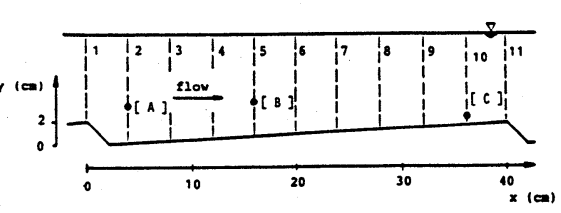

図-1 計测断面の配宣 のクレストから9波目のクレストにかけて4cm間隔で, 計11断面について水路中央縦断面内で行われた. 断面 配置を図-1に示す。 


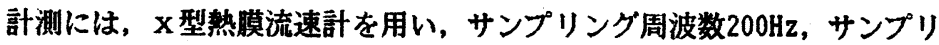
ング個数8192個とした。実験条件は，表-1に示す通りである。

河床波背面上の平均流速Uについて，対数型表示したのが，図-2である．再 付着点の直下流の底面付近の測点には対数関係の成立が認められるが, 流下 表-1 実験表件 方向に行くにつれて直線部 の傾きは緩くなっている. これは縮流に伴う加速効果 の影堷で流速分布が一粎化 $u / u_{\star}$ し, 内部境界層の発達が抑 制されるためと考えられる。

乱れ强度 $\sqrt{\overrightarrow{\mathrm{u}}^{2}}, \sqrt{\overrightarrow{\mathrm{v}}^{2}}$ の鉛 直分布を図一纤示す. $\mathrm{u}_{*}, \mathrm{~h}$ はそれぞれ，測定位置の摩 擦速度と水深である. 図中 の破線は, 禋津 ${ }^{1)}$ にるる乱 れ強度の指数分布式である. $\mathrm{y} / \mathrm{h} \geqq 0.3$ 領域では, 河床 波背面を流下するに従って 乱れ強度の系統的減少が見 られるが, 指数関係は, 継 続的に成立している. 一方, $\mathrm{y} / \mathrm{h} \leqq 0.3$ 領域では, 流れ が加速されるに従って乱れ 強度の相対的減少が見られ， この結果, 河床波背面上を 流下するに従って, 乱れ强 度分布の最大値は, 徐々に 上方に移動し, 剥離せん断

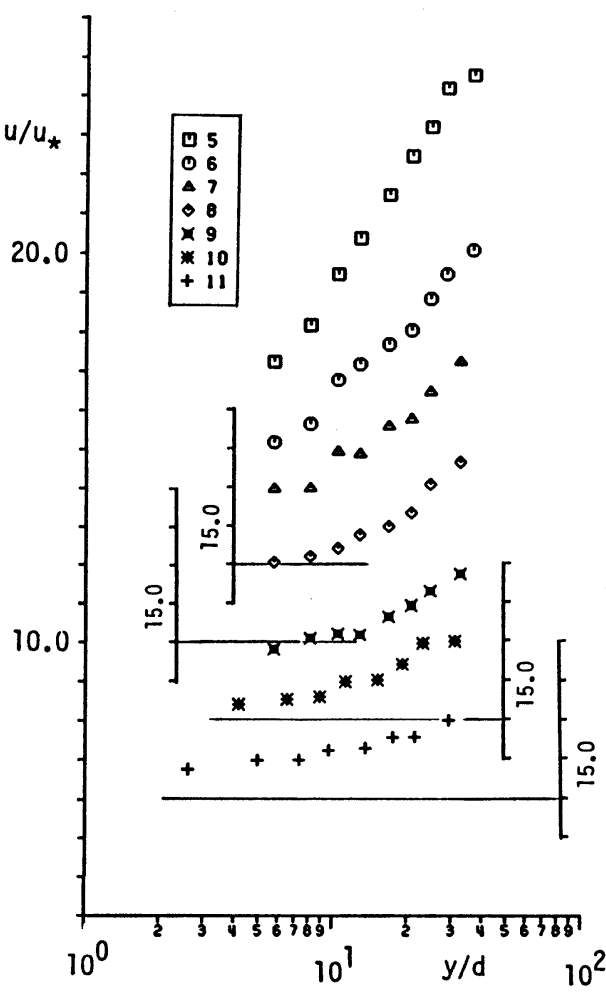

図-2 平均流速分布

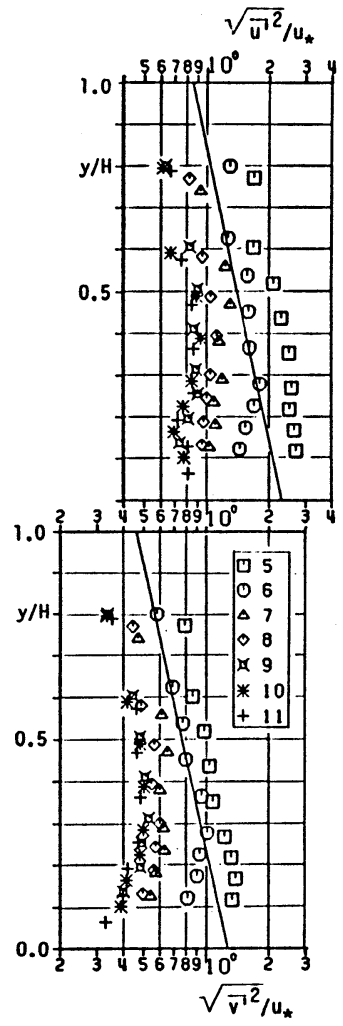

図-3 乱れ强度分布

層で生成された乱れが上昇渀の作用で上方へと広がっ 4. て行く様子が琴められる。

次に, 河床波背面での摩擦速度山*の詳価法について 述べる. 図-4は，(1)底面付近に対数則を適用した場 合，(2)Reynolds応力の直線分布領域を外㨂した場合， (3)k- $\mathrm{k}$ モデルによって洞動粘性俰数と底面付近の速 度勾配を求め $\tau, \tau=\rho u_{*}{ }^{2}=\rho\left(\nu+\nu_{t}\right)(d U / d y)$ から 評価した場合，を比較したものである.(1)，(2)の評

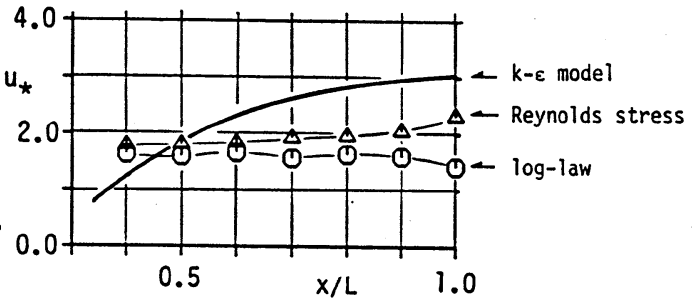

困-4 河床波背面上の摩擦速度

価法によると，摩擦速度の場所的な変化はそれほど顕著ではなく，特に(1)の方法では，クレスト付近で摩 擦速度の隇少か認められる.ところが, Raudkivi 2) を初めとする既往の測定結果によると，摩擦速度は河床 波背面上で，流下方向に漸增する傾向を示しており，この傾向は，(3)の評価法による結果に㩆著に現れてい る. 摩擦速度の濑増㑯向は，以下のような定性的考察からも支持される．河床波背面を流下するに従って加 速効果により流速分布が一様化され，底面付近の流速が増大する. 底面付近の流速は，摩擦速度と正の相関 関係にあるから, 流速の增加に伴い摩操速度も增加する. 以上のような理由からここでは, 摩擦速度を(3)の 
方法で評価することとする.

次に, 浮遊砂の輸送と関連の深いv'成分の skewnessの分布を図-5に示す，剥離域の上方で 負の方向への歪が，河床波背面上で正の方向へ の歪が，それぞれ生じている様子が, skewness の分布から理解できる.

更に，流速変動の確率分布に対する2 次元正

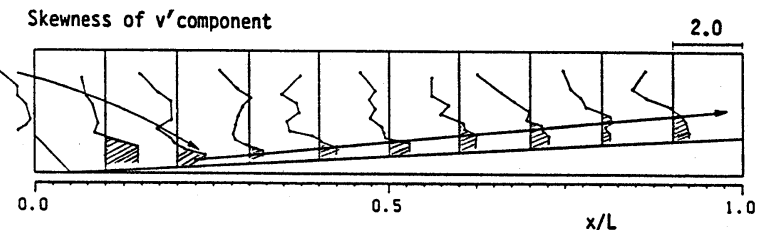

図-5 v'成分のskewnessの分布

規分布の適用性を検討したのが，眓-6である．どの测点においても乱れの水平・鉛直方向の周辺確率分布は それぞれ概ね正規分布で近似でき，結合確率分布についても uv の相関を考慮すれば，2次元正規分布は概 ね良好な適用性を有している.この事実は, 後に乱れ埸の模擬において 2 次元正規分布の成立を仮定するこ との根执となっている. また，河床付近の測点（図-6の[C]）については, skewness の值からも分かるよう に, v成分の周辺確率分布に負の方向への歪が琵められる.

なお, 図の[A] , [B] , [C]の位置は, 図-1に示してある.

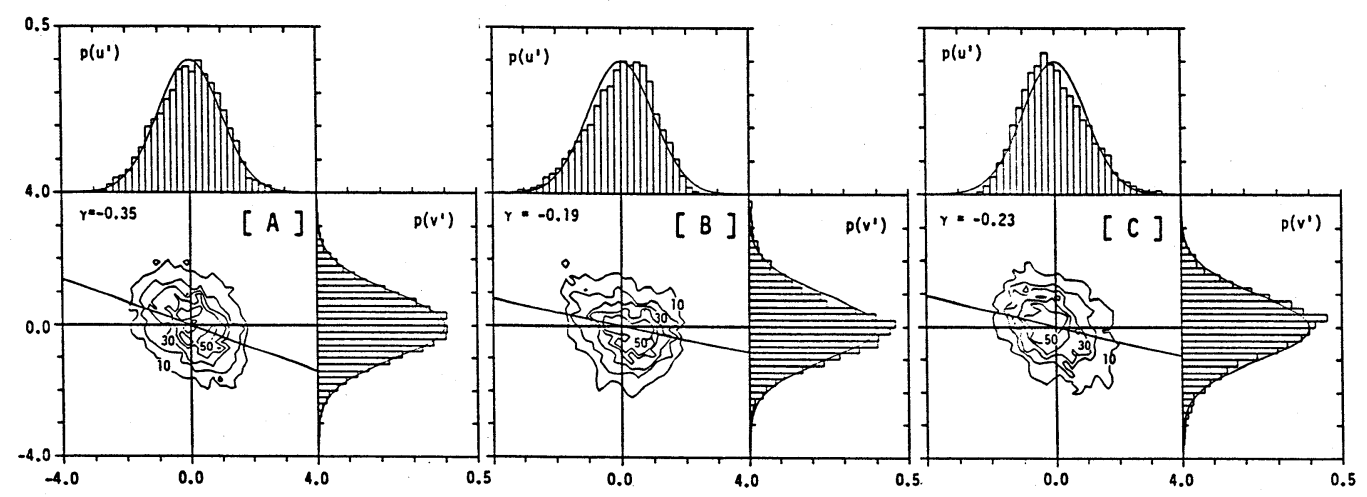

図-6 流速変動の確率分布

\section{3. 河床波上渀九の数值シミュレーション}

次に, 同㯼の条件で, 標準 $\mathrm{k}-\varepsilon$ 乱流モデルによる数值シミュレーションを実施し，その有効性を娭討した. 基碄方程式は, 連続式(1), 運動方程式(2)，(3), k方程式(4), $\varepsilon$ 方程式(5)であり，運動方程式中のP'は静水 压分布からの偏差圧力である.モデル定数は, Launder-Spalding による標洋推奖值(表-2)を用い, 座標系は, 図-7の様に採る.（ $\mathrm{g}$ =重力加速度， $\theta$ =河床勾配，その他の記号は，図-7参照）

$$
\begin{aligned}
& \frac{\partial U}{\partial x}+\frac{\partial V}{\partial y}=0 \\
& \mathrm{U} \frac{\partial \mathrm{U}}{\partial \mathrm{x}}+\mathrm{V} \frac{\partial \mathrm{U}}{\partial \mathrm{y}}=\mathrm{g} \cdot\left(\sin \theta-\frac{\partial \mathrm{h}}{\partial \mathrm{x}} \cos \theta\right)-\frac{\partial}{\partial \mathrm{x}}\left(\frac{\mathrm{P}^{\prime}}{\rho}\right) \\
& +\frac{\partial}{\partial \mathrm{x}}\left(-\overline{\mathrm{u}^{2}}\right)+\frac{\partial}{\partial \mathrm{y}}(-\overline{\mathrm{uv}})+v \nabla^{2 \mathrm{u}} \\
& \mathrm{U} \frac{\partial \mathrm{V}}{\partial \mathrm{x}}+\mathrm{V} \frac{\partial \mathrm{V}}{\partial \mathrm{y}}=-\frac{\partial}{\partial \mathrm{y}}\left(\frac{\mathrm{P}^{\prime}}{\rho}\right)+\frac{\partial}{\partial \mathrm{x}}(-\overline{\mathrm{uv}})+\frac{\partial}{\partial \mathrm{y}}\left(-\overline{\mathrm{V}^{2}}\right)+v \nabla^{2 \mathrm{~V}} \text { (3) } \\
& U \frac{\partial \mathrm{k}}{\partial \mathrm{x}}+V \frac{\partial \mathrm{k}}{\partial \mathrm{y}}=\frac{\partial}{\partial \mathrm{x}}\left(\frac{\nu_{t}}{\sigma_{\mathrm{k}}} \frac{\partial \mathrm{k}}{\partial \mathrm{x}}\right)+\frac{\partial}{\partial \mathrm{y}}\left(\frac{\nu_{\mathrm{t}}}{\sigma_{\mathrm{x}}} \frac{\partial \mathrm{k}}{\partial \mathrm{y}}\right)+G-\varepsilon \text {...(4) } \\
& G=v_{t}\left(2\left(\left(\frac{\partial U}{\partial x}\right)^{2}+\left(\frac{\partial V}{\partial y}\right)^{2}\right)+\left(\frac{\partial U}{\partial y}+\frac{\partial V}{\partial x}\right)^{2}\right) ; v_{t}=C_{\mu k}{ }^{2} / \varepsilon \\
& U \frac{\partial \varepsilon}{\partial x}+V \frac{\partial \varepsilon}{\partial y}=\frac{\partial}{\partial x}\left(\frac{\nu_{t}}{\sigma_{E}} \frac{\partial \varepsilon}{\partial x}\right)+\frac{\partial}{\partial y}\left(\frac{\nu_{t}}{\sigma_{E}} \frac{\partial \varepsilon}{\partial y}\right)+\frac{\varepsilon}{k}\left(C_{1 E} G-C_{2 E} \varepsilon\right)
\end{aligned}
$$

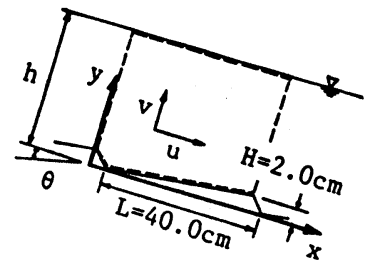

\begin{tabular}{|c|l|l|l|l|}
\hline $\mathrm{C}_{\mu}$ & $\mathrm{C}_{1 \mathrm{E}}$ & $\mathrm{C}_{2 \mathrm{E}}$ & $\sigma_{k}$ & $\sigma_{\mathrm{E}}$ \\
\hline 0.09 & 1.44 & 1.92 & 1.00 & 1.30 \\
\hline
\end{tabular}


境界条件は，(a)壁関数（河床面の条件），(b)自由水面による乱れエネルギー娍袁の効果を考慮した螎津 -中川 ${ }^{3)}$ の方法（減衰係数 Dw=0.8 ,水面の条件）（c)1波手前の流出部の值を流入部に代入（流入部の条件） である. 計算結果と熟膜流速計によ る計測結果との比較を図-8に示す。

平均流速Uについては, 計測值と計 算值との対応は良好である. 剥離域 を伴う第2断面から第4断面にかけて， 混合層型の流速分布が発達している. 再付着点から下流へ向けて内部境界 層が発達するが，缩流による加速効 果により境界首の発達が抑制され， 縮流効果のない段落ち流れと比べる と，境界層厚の增加率はかなり小さ いと考えられる.クレスト部の流速 分布が段落ち流れに比べて一模化す ることについては，中川・濡津ら 4)がレーザー流速計による計测によ っても確珰しており, 編流効果と流 れのhistory効果を原因として挙げて いる.これまでの計測結果から指摘 されてきたこのような流れの特性を 本計算結果は良好に表現しでおり， k- $\varepsilon$ モデルの有効性が確珰された。

Distributions of liean Velocity $U$

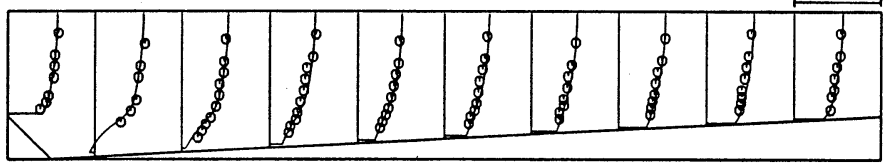

Distributions of Hean Velocity $V \quad 8 \mathrm{~cm} / \mathrm{sec}$

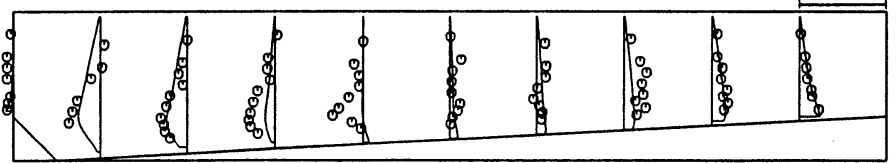

Distributions of Turbulence Intensities $\sqrt{\overline{u^{\prime 2}}} \quad 4 \mathrm{~cm} / \mathrm{sec}$
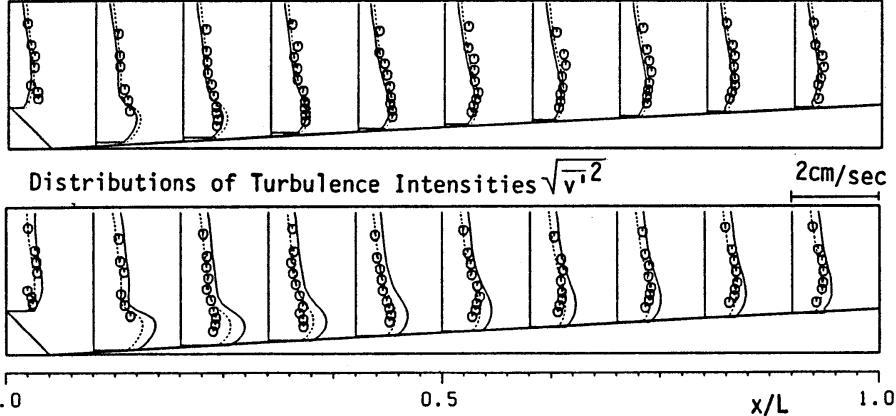

困-8 k- $\varepsilon$ モデルによる計算結果と計測結果の比較

平均流速り成分については，剥離域の上部で下降流が再付着点より下流で上昇流が存在することが計算結果 から理解できる. V成分はU成分に此べてオーダーが小さいことを考虎すると, 計測值との対応も概ね良好と

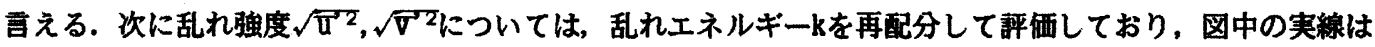

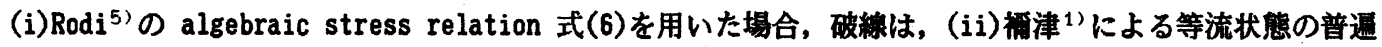
関数表示の係数の比 (式(7)) を用いた場合である. 計算結果は, 乱蚛度の剥離せん断層に沿う急增と河床 波背面での鉛直方向への拡散を良好に示している，kの再配分法としては，(ii)の方が計測值との対応は良く， 等流状態の配分比率が加速・減速を伴う河床波上の流れにおいても，ほぼそのまま適用されるものと考えら れる。

$$
\begin{aligned}
& \overline{u_{1} u_{3}}=k\left(\frac{2}{3} \delta_{1 j}+\frac{(1-\alpha)\left(\frac{P_{1}}{\varepsilon}-\frac{2}{3} \delta_{1,} \frac{P}{\varepsilon}\right)}{c_{1}+\frac{P}{\varepsilon}-1}\right) \\
& \alpha=0.764, c_{1}=1.5 \quad\left(P_{1 \jmath}=\text { stress production } u_{1} u_{j}, \delta_{1 j}=\text { Kronecker delta }\right) \\
& \sqrt{\widetilde{\mathrm{u}}^{2}}=1.10 \mathrm{k}, \sqrt{\overline{\mathrm{v}}^{2}}=0.34 \mathrm{k}
\end{aligned}
$$

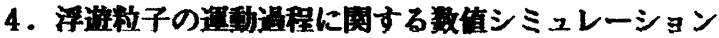

これまでの検討から，河床波上流れの時間平均的特性を表現する手段としてk-をモデルが有効であること が明かとなったが, 更にk- $\varepsilon$ モデルから得られる情報をできる限り詳細に利用した浮遊粒子の運動過程の追 跡を試みることにする。

砂粒の運動方程式は, Basset項を省略したTchenの式，抗力係数は，Rubey型とする. 瞬間流速の場は，先 
のk- $\varepsilon$ モデルによる数值シミュレーションにより計算された平均流成分・变動成分と乱数発生の方法を用い てモデル化される. 先ず, 粒子の存在位置での平均流成分U,V及び乱れ强度 $\sqrt{\overrightarrow{\mathrm{u}}^{2}}, \sqrt[\vec{v}^{2}]{ } \mathbf{2}, \mathrm{k}-\varepsilon$ モデルによ る計算結果を線形補間して求める. 次に, 乱れ強度 $\sqrt{\bar{u}^{2}}, \sqrt{\bar{v}^{2}}$ と乱数発生の方法とを組み合わせて, 変動成 分の瞬間值 $u^{\prime}(t), v^{\prime}(t)$ を求めるが, その際の比較的简便な手法として,(1)単純Monte-Carloシミュレーショ ン.(2) 1 次元Markov過程モデルを組み込んだMnote-Carloシミュレーションがある.

Yalin-Krishnappan (6) を初めとする従来のこの種の研究のほとんどが, 変動成分の瞬間值を与えるのに(1) の手法 (式(8)）を用いており，粒子運動の履歴性を無視した取扱いとなっている.これに対して，(2)の手 法 (式(9)) には, Markov過程モデルが組み込まれているため, 時刻 $t+\Delta t$ 変動成分は時刻 $t$ 変動成分の曈 每が残存する粎に決定される. 同一出発点から出た粒子の運動軌跡を(1)，(2)の方法で模擬し，比較したのが 図-9である.（2）の手法によると粒子は広節囲に分散し, 河床波を何波も越えて浮遊する粒子の轨跡が再現さ れている.この粎な粒子の存在は, 実験の際の観察から確珰されており, (2)の手法は(1)の手法より高い現 象の再現性を有していると考えられる.

$$
\begin{aligned}
& u^{\prime}(t)=\sqrt{\bar{u}^{2}} \cdot r \\
& v^{\prime}(t)=\sqrt{\bar{v}^{2}} \cdot r \\
& u^{\prime}(t+\Delta t)=\alpha_{u} u^{\prime}(t)+r_{u} \\
& v^{\prime}(t+\Delta t)=\alpha_{v} v^{\prime}(t)+r_{v}
\end{aligned}
$$

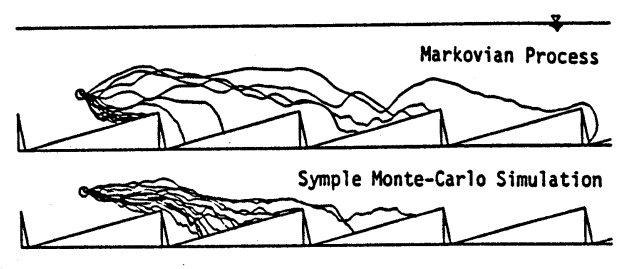

困-9 粒子の運動軌跡

式(9)は, 時刻 $t+\Delta t$ の変動成分が, 時刻 $t$ 変動成分に関する項とランダム成分 $r_{u}, r_{v}$ の和で与えられるこ とを示しており， $\alpha_{\mathrm{u}}, \alpha$ vは それぞれ $\mathrm{v}, \mathrm{y}$ 方向のLagrange的自己相関俰数で, 粒子の存在する位置 $(\mathrm{x}, \mathrm{y})$ の閉

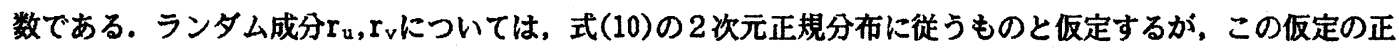
当性は，2節の図-6からも支持される.

$$
f\left(r_{u}, r_{v}\right)=\frac{1}{\sqrt{2 \pi} \sigma_{r u}} \exp \left(-\frac{r_{u}{ }^{2}}{2 \sigma_{r u}{ }^{2}}\right) \frac{1}{\sqrt{2 \pi} \sigma_{r v} \sqrt{1-\gamma^{2}}} \exp \left(-\frac{1}{2\left(1-\gamma^{2}\right) \sigma_{r v}{ }^{2}}\left(r_{v}-\gamma \frac{\sigma_{r v}}{\sigma_{r u}} r_{u}\right)^{2}\right)
$$

$\left(\sigma_{\mathrm{ru}}, \sigma_{\mathrm{rv}}=\right.$ ランダム成分の分散值, $\gamma=$ ランタム成分の相関係数)

計算の時間スケールについては, $A B S$ 粒子 $(\sigma / \rho=1.03, d=0.128 \mathrm{~cm})$ の変動に対する応答特性を考慮して, 粒 径の 0.2 倍程度の応答が得られるような变動周期を用い, $\Delta \mathrm{t}=0.031 \mathrm{sec}$ とした.ここで粒径の 0.2 倍程度の 応答を基蕉值としたのは, 粒子運動の追跡の精度が粒径より1オーダー低い程度の值で充分であると考えた ためである.

\section{5. 河床波背面上の非平衡浮進秒湜程}

次に，先の方法で河床波上の粒子の運動を追跡し，その累積として浮 遊粒子の存在確率密度を評価し，濃度分布の実験結果と比較する. 実駼 は, 表-3の条件でABS粒子（粒径 $0.128 \mathrm{~cm}$, 比重1.03）を用いて行われ, ビデオ解析によって濃度分布が調べられた，計算では先す，上流㑡クレ 表-3 実騟条件 ストでの粒子の存在確率密度が実験から得られる浱度分布と適合する棣に, 高さ方向に粒子を配置した。そ こから個々の粒子の運動を追跡し，各断面を通過する毎にその位置を配列に記録した。追跡は砂粒が河床に 到達するまで続けられた。浮遊砂への還移については, 上流側と下流㑡のクレストの浱度分布が平衡に達し た状態では，掃流砂から浮遊砂への屒移と浮遊砂から掃流砂への復㷌が平衡していると考えられるので，予 め河床に到達した粒子の個数をカウントしておき, それを遷移强度で重み付けして河床付近の各出発点に配 分し, 運動軌跡を追跡し, その結果を上流㑡クレストから出発した粒子の追跡結果に足し合わせて浮遊粒子 
の存在確率密度を求めた。 なお, 遷移强度については河床波背面上での掃流力の分布を考慮して, 中川ら7 の算定法により逻移確率密度を算定し，これと镸移强度とが相似であるとして与えた。

この様にして各断面で浮遊粒子の存在確事密度を求め, 実験による浮遊砂の搌度分布と比䡴したのが，図 -10である.

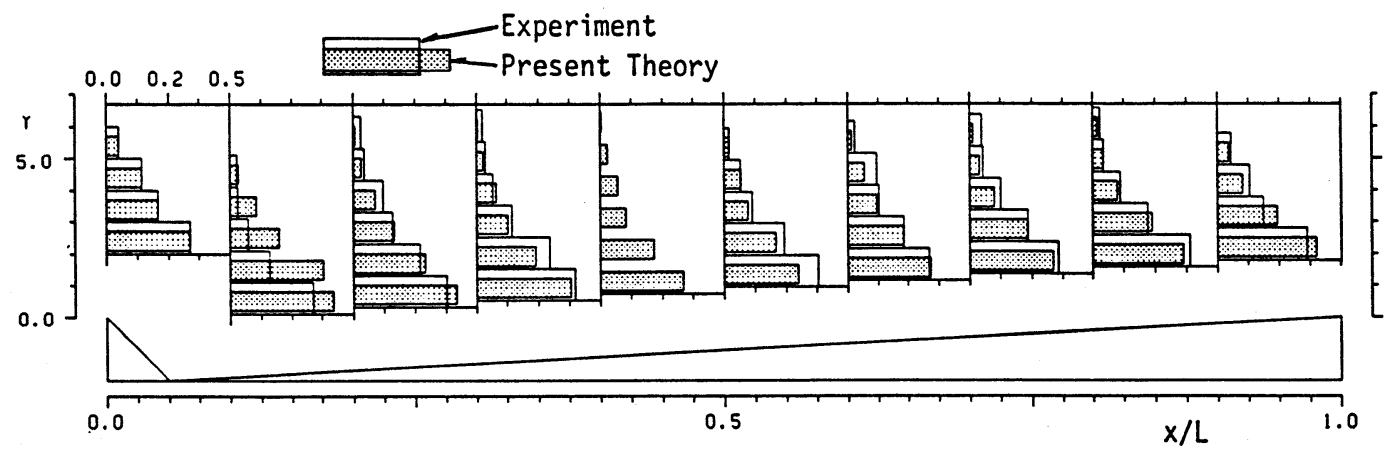

図-10 河床波上の浮遊粒子の存在確率密度

ビデオ解析では, 河床から高さ方向に1c磵隔で区切られた断面内の存在個数を集計した.シミュレーショ ンでは図-10に表示したよりも詳細な分布形が得られているが, 実験値と同一の集計法により処理して, 直接 比較が可能なように表示している，上流側のクレストから再付着点付近にかけて浱度重心が流下方向に徐々 に低下するが，再付着点より下流では，河床波背面上を流下するにつれて，掃流砂からの還移による浮遊砂 の生成と上昇流の作用によって浱度重心が徐マに上昇し，第6断面付近で発達過程はほほ終了し，それより下 流側では比較的変化が緩やかで，ほぼ一定の分布形となることが，図-10から分かる. 計算結果の実験との対 応は，第2断面を除けば概ね良好である. 第2断面の誤差は, この断面が剥離泡の真上にあり, 剥離泡内は多 数の粒子が回転運動しいて粒子の判読が難しいことに起因すると考えられる.

\section{6.あとがき}

河床波上の流れの様に剥離を伴う複雑な流れに対しても，その時間平均的楎造を把握する上では, $k-\varepsilon モ$ デルが有効な手法となり得ることが明かとなった，更に，流れ場の時間平均的構造が既知であれば,Markov過 程を組み込んだNonte-Calroシミュレーションにより, 浮遊粒子の運動過程が良好に表現されることが分かっ た. 浮遊粒子の運動距離が長いため, 浮遊粒子の全運動経路を実験によってLagrange的に捉えることは不可 能であり，それ故，個々の粒子の運動軌跡がどの程度正確に追跡されているかは，確認できなかった。しか し, 個々の粒子の運動の集積としての浮遊砂の存在確率密度については, シミュレーション結果と実験結果 との対応は良好であり, 複雑な非一粎境界条件を有する流れ場に対する本シミュレーションの有効性か碓認 された.

\section{参考文戴}

1）螎津家久：開水路流の乱流構造に関する基礎的研究, 京都大学学位論文, 1977.

2) Raudkivi : J.Hydraulics Div., Proc. ASCE, HY-6, pp.15-33,1963.

3）襧津家久・中川博次：京都大学防炎研究所年報, 第29号B-2, pp.90-116, 1986.

4）中川博次・螎津家久・松本利典・金沢文彦：第33回水理講演会論文集, pp.475-480, 1989.

5) Rodi : ZAMM56,T219-T221, 1976.

6) Yalin M. S. and B. M. Krishnappan : International Symp. on River mechanics, A52-1-12, 1973

7）中川博次・辻本哲郎・村上正吾・後藤仁志：第32水理講演会論文集, pp.529-534，1988. 